\title{
Jew-Hatred in the Islamic State Organization's (ISIS) Ideology
}

\author{
Shaul Bartal \\ Bar-Ilan University, Ramat Gan, Israel
}

\begin{abstract}
In October 2015, an ISIS member speaking fluent Hebrew warned that soon there would be no Jews left in Jerusalem or in the rest of the land called "Israel". The Islamic State in Iraq and Syria (ISIS) will fulfill this mission according this Salafi-Jihadism group. ISIS ideology holds that it is first necessary to fight against the near enemy (the Arab states) but the last apocalyptic battle will be with the Jews (the far enemy). The purpose of this article is to reveal and present the development of Jew-hatred from al-Qa'ida and up to the present doctrine of ISIS.
\end{abstract}

Keywords: ISIS, Israel, Jews, al-Qā‘ida, Abū Mus‘ab az-Zarqāwī, Abdu’llāh 'Azzām, Ayman az-Zawāhirī

In October 2015, an ISIS member speaking fluent Hebrew warned that soon there would be no Jews left in Jerusalem or in the rest of the land called Israel. "We will enter al-Aqsa mosque as conquerors", he said, "and our car bombs will strike the ramparts of the Jews" (Kais, 2015a).

How dangerous is ISIS really to Israel and to the Jews? The answers vary. Some analysts believe that ISIS does not offer an independent serious strategic challenge to Israel (Efraim, 2015). This paper intends to prove otherwise.

ISIS ideology believes that the natural progress for the organization is first to establish a state and then implement sharia law. Once this has taken place, only then will it be the time for additional world conquests, including Israel, and the widening of its sphere of influence.

The ISIS organization has set out goals — short-term, medium-term, and long-term. ${ }^{1}$ The extermination of the Jews and the State of Israel, despite its importance to the ISIS organization, is found on ISIS' long-term goal list.

\section{A Short History of ISIS}

The ISIS organization grew out of the Jamā'at al-Tawhīd wa-al-Jihād (JTJ) organization (founded in the year 1999 by Abū Mus'ab az-Zarqāwī [d. 2006] ${ }^{2}$ who previously founded the Bay'at al-Imam organization in 1994). In March 1994, Zarqāwī was arrested by the Jordanian police along with his mentor Abu Muhammad al-Maqdisi (b. 1959). This team planned to use their weapons in a coordinated attack on an Israeli outpost along the border. Their plan called for striking the guard station with back-to-back suicide bombs followed by small arms' fire (Joby, 2015, pp. 55-56). The Jewish state was 'Abū Mus'ab az-Zarqāwī’s first target.

Zarqāwī, who was born in Jordan, fought in Afghanistan during the 1980s. In Afghanistan he met Usāmah bin Lādin (d. 2011) and Sheikh Abdu'llāh Yūsuf 'Azzām (d. 1989), the leaders of al-Qā'ida. In 2003, Zarqāwī,

Shaul Bartal, Ph.D., Lecturer on Palestinians Affairs, Middle Eastern Studies, Bar-Ilan University.

${ }^{1}$ Uzi Rabi, Back to the Future, the Middle East in the Shadow of the Arab Spring (Tel-Aviv: Resling, 2016), pp. 114-129. Elliot Friedland, Special Report, 13-16. Robin Simcox, "AQAP's Ideological Battles at Home and Abroad", Current Trends in Islamic Ideology, vol. 18(2015), 19-20.

${ }^{2}$ His given name was 'Ahmad Fadīl an-Nazāl al-Halāyla. 
became active in Iraq where he joined the al-Qā'ida fight against American coalition forces (Joby, 2015, pp. 51-55).

In 2004, Zarqāwī's organization swore allegiance to Usāmah bin Lādin and changed its name to Tanzīm Qā'idat al-Jihād fĩ Bilād ar-Rāfidayn (Organization of the Jihad Base in Mesopotamia). ${ }^{3}$ In 2011, the organization joined the civil war in Syria on the side of the rebels. This brought about another name change-The Islamic State in Iraq and al-Sham (ISIS). In February 2014, ISIS split from al-Q̄āida due to a difference of opinion between Abū Bakr al-Husayni al-Baghdādī, the ISIS leader (since 2010) ${ }^{4}$ and 'Ayman az-Zawāhirī, the al-Qā'ida leader. After al-Mōsul, the second largest city in Iraq was captured (on June 29, 2014), al-Baghdādī, declared himself Caliph. ${ }^{5}$ He then successfully organized a hierarchal system which was able to run countries and provide services to the residents of the entire area controlled by the organization. ${ }^{6}$

The organization's success in Syria and Iraq and the establishment of a state (which is a nation as defined by the Islamic religion [al-ummah]), represents the desire for a Caliphate by Muslim zealots - ever since the cancelation of the Ottoman Caliphate in 1924. From an ideological point of view, there are no basic ideological differences between ISIS and other Salafist-jihadist organizations active in the Arab world. ${ }^{7}$ There are, however, two fundamental differences:

(1) The timing of the announcement of the establishment of a Caliphate.

(2) The appropriate reasons for establishing a Caliphate.

\section{The Uniqueness of the ISIS Organization}

ISIS is a non-statesmen-like violent player in the Middle East playing field. It works to undermines state sovereignty. Its model differs substantially from the models of the other terrorist organizations operating in the area.

Terrorist and guerilla organizations, such as Hezbollah, the Palestinian Islamic Jihad and branches of al-Qā'ida, do not, for the most part, conquer territory but rather operate in "hit and run" patterns. Their aim is to tire out and scare their opponents, leading to the withdrawal of these opponents from existing territory. ISIS, on the other hand, desires to capture land, control it and then govern it. The use of the word "state" by ISIS does not refer to a modern nationalistic state with territorial boundaries but rather the idea of a Caliphate and an Islamic space not bounded by geographically expressed boundaries. If ISIS succeeds in its goals, this will lead to the creation of a totally new type of space in the Middle East, one which is not cut out from the historical Sykes-Pico agreements and which is not subordinate to any international laws or international justice but only to the Islamic vision. ${ }^{8}$

\footnotetext{
${ }^{3}$ Elliot Friedland, Special Report, The Islamic State (Washington D.C.: The Clarion Project, May 10, 2015), 7-8. Available at http://www.clarionproject.org/. The popular name of the group was al-Qā ida in Iraq (AQI).

${ }^{4}$ His real name is Awwad Ibrahim Ali al-Badri al-Sammarrai. Patrick Cockburn, The Rise of the Islamic State (London: Verso, 2015), 43-45.

5 A full translation of this declaration is in David Cook's book, Understanding Jihad (Oakland: University of California Press, 2015), 224-236.

6 Ibid., 164-169; Carmit Valensi, "Non-Statesmen Players: Theoretical Limitations against the Changing Reality in the Middle East", Army and Strategy, vol. 7, Mar. 1, 2015, 67-68. For more information about the al-Mō 'ul occupation by ISIS see also Talha Abdulrazaq and Gareth Stansfield, "The Enemy Within: ISIS and the Conquest of Mosul", The Middle East Journal, vol. 70, Autumn 2016, 525-542.

${ }^{7}$ Martin Kramer, "Coming to Terms: Fundamentalists or Islamists?," Middle East Quarterly, vol. 10 (Spring 2003), 65-77.

8 "The Islamic State Restores the Caliphate", Pieter van Ostaeyen, Musings on Arabism, Islamicism, History and Current Affairs, Jun. 29, 2014, https://pietervanostaeyen.wordpress.com/2014/06/29/the-islamic-state-restores-the-caliphate/. Uzi Rabi, "The Alternative Map: The New Geopolitical Panorama of the Middle East", in the article by Mustafa Kabhah and Ronen Yitzhak (ed.), Hamizrah Hehadash, vol. 54 (2015), 186-187; Patrick Cockburn, The Rise of the Islamic State, 27-29.
} 
The organization's success in establishing an Islamic State in the Middle East and in receiving support and loyalty from many residents of the Sinai Peninsula, Libya, etc., is a real threat not only to the Shiite communities (including the Druze and the Alawite), who are defined as the enemies of Islam but to all minorities living in those spaces, including the Jews. The dawah (invitation to Islam) in ISIS thought is aimed at the enemies of Islam. At the top of the list are the Jews who have always been described in the organization's doctrine as "the enemies of humanity and God".

In a letter sent by 'Ayman az-Zawāhirī to Abū Mus'ab az-Zarqāwī, on July 9, 2005, az-Zawāhirī detailed the stages of his plan for al-Qā'ida (which later became ISIS in Iraq):

First Stage: Expel the Americans from Iraq.

Second Stage: Establish an Islamic authority or emirate and then develop and support it until it reaches the level of a Caliphate.

Third Stage: Extend the jihad wave into the secular countries surrounding Iraq.

Fourth Stage: Start a clash with Israel since Israel's ideology, was only established to challenge the Islamic entity. ${ }^{9}$

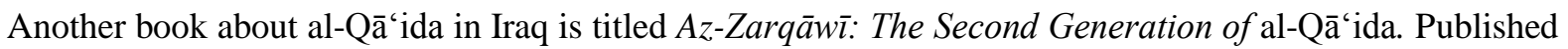
in 2005, this book foretells that al-Qā'ida will reach Israel's border without Israel being able to carry out preemptive or precautionary strikes. This book also predicts that the international balance will change and the majority of nations will join al-Qā‘ida's side (Eric, 2015, pp. 148-150; Yassin, 2005). In al-Qā‘ida's and ISIS' eyes, Israel is the "far" enemy whose end will only come after the victory of the "near" enemy and the establishment of the Islamic caliphate (Brooke, 2011).

\section{Jews as Initiators of Worldwide War Against Islam}

The ISIS organization does not hide its hatred for the Jews and publically prepares for an apocalyptic battle against them. In the first advertisement of the Dābiq magazine (This name is taken from the Islamic eschatology of the prophecy of the end of days), the magazine emphasizes the following division:

Amīr al-Mu'minīn said: "O Ummah of Islam, indeed the world today has been divided into two camps and two trenches, with no third camp present: The camp of Islam and faith, and the camp of kufr [infidels] and hypocrisy-the camp of the Muslims and the mujahidīn [Holy War fighters] everywhere, and the camp of the Jews, the Crusaders, their allies, and with them the rest of the nations and religions of $k u f r$, all being led by America and Russia, and being mobilized by the Jews". 10

ISIS believes that international Judaism is the cause of all evil in this world. This is an opinion that has been accepted for generations as a reason for the existence of anti-Semitism. ISIS also believes that the United States and its former President Barack Obama were a cause of evil. This is how al-Qā'ida's describes Israeli-American relations:

On 7 August 2014, the Crusader, apostate Barack Obama announced to the world the continuation of the American crusade against Islam and the Muslims of Iraq, only to prove to his followers that there is no difference between his partisan politics and that of his predecessor-Bush-apart from cosmetic, superficial touches. His decisions also expose the hypocritical politics of America that only serve the interests of their Jewish ally, Israel, and their own capitalist gluttony. So

\footnotetext{
9 Office of the Director of National Intelligence, "Letter from al Zawahiri to Zarqawi”, Jul. 9, 2005, released to the public Oct. 11, 2005, https://fas.org/irp/news/2005/10/dni101105.html.

10 “The World has Divided into Two Camps", Dabiq: The Return of Khilafah, Issue 1, Ramadan (Jul. 2014), 10.
} 
while genocide is committed by the [Nouri] al-Maliki [Iraqi former Prime Minister], Assadi [Bassar al-Assad troops], and Israeli forces against the Muslims via systematic massacres, chemical warfare, rape and starvation by siege, Obama watches with euphoria. However, when his brothers in Yazidi Satanism and Peshmergan Zionism are killed, he panics. ${ }^{11}$

Already in the 1940s, the Muslims perceived the Jews as the leaders of world heresy who used their influence to control the world as set out in the booklet, The Protocols of the Elders of Zion. This type of radical Islamic thinking appears in Hajj Muhammad Amin al-Husayni’s booklet against the Jews, Islam and Judaism, which appeared in German and Bosnian. ${ }^{12}$ This booklet declares that the Jews have been described as a corrupt, anti-Islamic nation since the beginning of Islam in Medina in the seventh century, The Jews even tried to kill Muhammad a number of times. It was only after Muhammad exiled the Jews, had some Jews from Medina killed, captured Khaybar, exiled and killed the rest of the Jews and succeeded in standing up to the international coalition that rose up against him, that the Islamic empire flourish.

The Jews who fled to Khaybar, however, would not concede defeat and decided to avenge themselves on Muhammad. For that purpose, they turned to other Khaybar Jews and to the Jews of Taima and of Wadi Qura. Together they plotted a conspiracy: With large sums of money, they agitated non-Muslim Arab tribes to attack Medina. When Muhammad discovered their plan, he quickly armed his men and set out toward the plotters' base in Khaybar. Muhammad's companions captured Khaybar and expelled most Jews from the site. ${ }^{13}$

In this booklet the Jews are also accused of trying to poison Muhammad with a poisoned sheep. Muhammad did not eat the sheep but his taster who did eat it was poisoned and died a slow death. When the Jews saw that they could not beat Muhammad in battle, they began to incite non-Muslims and Muslims against the believers. The Mufti Hajj Muhammad Amin al-Husayni (d. 1974) summarized it thusly: "That idea has been even better expressed by words of Muhammad: 'It will never be possible for you to see a Muslim and a Jew together without a secret intention in the [heart of the] Jew to destroy the Muslim." "14 And that is what they still believe.

The Mufti, who was also the head of the Muslim Brotherhood branch in Palestine (1945-1948), was not the only Jew hater. Hassan al-Banna (d. 1949), the founder of the organization also had firm opinions against world Judaism and its war against Islam. In 1938, at the Muslim Brotherhood conference which took place in Egypt, a translation of Hitler's Mein Kampf and The Protocals of the Elders of Zion were presented in Arabic (Patterson, 2015, pp. 91-93). Among all the anti-Jewish religious leaders of the Muslim Brotherhood, the leader who presented his hatred for the Jews in the most convincing philosophical manner and who enabled the generations that followed him to also hate the Jews was Sayyid Qutb. During the 1950s, Sayyid Qutb, who was the main philosopher of the Muslim Brotherhood, publicized his book, Our War against the Jews. Already in this book, he determined that Jews stood behind every conspiracy against Islam.

The Islamic nation has never stopped suffering from the Jewish plots and their deceptions. Already [at the beginning of Islam] the forefathers of the nation suffered from the frauds and the intrigues of the Jews. Despite the fact that the Muslim nation doesn't receive any benefits, with all the sorrow in this Qur'anic battle and with the direct guidance of Islam [that are derived from them]. ${ }^{15}$

\footnotetext{
11 "In the Words of the Enemy", Dabiq, A Call to Hijrah, Issue 3 (Aug. 2014), 35. On page 36, Obama is shown with a skullcap on his head near the Wailing Wall.

12 Veliki Muftija Jeruzalemski Hadži Emin el-Huseini, Islam I Židovstvo (Zagreb: Hrvatski tiskarski zavod, 1943).

13 Trans. by Boris Havel, "Hajj Amin Husseini's Anti-Semitic Legacy”, Middle East Quarterly, vol. 22 (Summer 2015$), 4$.

14 Ibid, 11

15 Sayyid Qutb, Ma 'rakatuna ma 'al-Yahüd (Cairo: Dar Al-Sharuq, 1993), 20.
} 
Qutb argues that there is a reason behind the Qur'an's comparison of the Jews to polytheists in the verse: "You will surely find the worst enemies of the Muslims to be the Jews and polytheists" (Qur'an, Sura 5, verse 82). Allah's aim, according Qutb, is to show that the Jews, even though they are the People of the Book and therefore closer to faith, in reality they are the enemies of the believers and even worse than the polytheists. ${ }^{16}$ Qutb continues (in the way of Sayyid Abul 'Ala Maududi) and describes the Jews as the servants of the devil: "The blackest devil and the end source of the worst anti-Islamic machinations". ${ }^{17}$

David Patterson has analyzed Qutb's doctrines based on his writings:

Parallel the opposition between Dar al-Islam and the Dar al-Harb, the "realm of Islam" and the "realm of war", says Qutb is the distinction between hizb Allah, or "Party of Allah", and the hizb al-shaytan or "Party of Satan". The universal treat to the house of Islam and the Party of Allah is the satanic evil of the Jews and Judaism. ${ }^{18}$

An additional philosopher from among the founders of the al-Q'a' ida organization is the Palestinian Sheikh Abdu'llāh Yūsuf 'Azzām. He developed Qutb's philosophy and even dedicated a book to him where he called him "a giant Islamic thinker".

In his book, Questions and Answers on the Philosophy of Jihad, 'Azzām argues that one needs to also fight against the Jews who live outside of Israel as they donate to and support the Jews in Palestine. ${ }^{19}$ Although he was a Palestinian, "Azzām argues for the first time that the destruction of the Jews and the freeing of the entire Palestine is a goal for the far future and not for immediate implementation. He believed that the enemies of Islam in Afghanistan and wherever else they were found should be fought first. He believed that first one needed to fight against the "fake Muslims" and free the Islamic lands before freeing Jerusalem from the Jews. ${ }^{20}$

If only the Muslims would apply their Lord's command [to jihad], and implement the laws of their shari'ah concerning the General March for just one week in Palestine, Palestine would be completely purified of Jews. ${ }^{21}$

'Azzām's son, Hudhaifa, fought with 'Abū Mus'ab az-Zarqāwī in the Afghan war. The connections between these two people shaped az-Zarqāwī's views against the enemies of Islam and the way to fight against them. ${ }^{22}$ 'Azzām's ideas were adopted by the ISIS organization.

'Azzām also described the way to establish a new Caliphate which would fulfill his vision:

Will the Caliphate fall from the sky? Now in Afghanistan there is jihad for ten years already. There are outstanding leaders [in battle] one of whom will turn into the Caliph. Even if there will be a long jihad in Palestine which will lead to victory over the Jews. In this case one of the jihad commanders will turn into the Caliph. [Emphasis by author]. ${ }^{23}$

The philosophy of Sayyid Qutb and Abdu'llāh 'Azzām enabled Islamic organizations such as the Egyptian Islamic Jihad and al-Q̄̄'ida to act against the Islamic regimes in order to establish the Islamic society that Qutb

\footnotetext{
16 Ibid, 30-34. Ronald N. Nettler, Past Trails and Present Tribulation, A Muslim Fundamentalist's View of the Jews (Oxford: Pergamon Press, 1987), 59-61.

17 Ronald L. Nettler, Past Trails and Present Tribulations, 28.

18 David Patterson, Anti-Semitism and its Metaphysical Origins (New York: Cambridge University Press, 2015), 89-90.

19 Abdullah Yusuf 'Azzam, Al-Asaile wa-al-Ajwaba al-Jihadiya (Pashwar: Maktab al-Khidmat al-Mujahideen, n.d.), 59-60.

20 Shaul Bartal, Jihad in Palestine: Political Islam and the Israeli-Palestinian Conflict (New York and Abington, Routledge, 2016), 11-12. Abdullah Yusuf Azzam, Al-Asaile wa-al-Ajwaba al-Jihadiya, 41-42.

${ }_{21}$ David Patterson, Anti-Semitism and its Metaphysical Origins, 103.

22 Joby Warrick, Black Flags, 51-55.

23 Abdullah Yusuf Azzam, Al-Asaile wa-al-Ajwaba al-Jihadiya, 64-65.
} 
preached about, the only one that represented the will of God. ${ }^{24}$ 'Ayman az-Zawāhirī explained why they acted against Arab states such as Jordan, Egypt, and Saudi Arabia. According to the (ignorant) new jahiliyyah outlook developed by Qutb, Qutb maintained that jahiliyyah did not represent just one given historical situation but indicated certain circumstances that repeat themselves. According to az-Zawāhirī, when an Islamic society adopts a monarchy, a democracy or any other type of rule that has been created by man, it turns into a jahiliyyah society, a society that espouses partnership (shirq) with God and thus turns into a type of society of heresy. ${ }^{25}$ This is the justification for acting against Arab states (the near enemy) — to return Muslims to the faith and liberate Jerusalem from the Jews (the far enemy). Zarqāwī's final public comments before his June 2006 death proclaimed: "We fight in Iraq and our eyes on [sic] Bait al-Maqqdis [Jerusalem] we fight in Iraq and our eyes are on Medina". ${ }^{26}$ Bin Lādin also made similar statements in a March 2009 video release. ${ }^{27}$

ISIS adopted the ideology of Qutb and 'Azzām and tries to follow in their footsteps. The Jews, as the servants of the devil and as the killers of the prophets, will be punished by the Prophet who will rise up and take out his revenge on them for killing his prophets and for all the evil that they bring. Jews also make fun of Islam and curse the Prophet. Jewish experts in Middle-Eastern affairs, such as Daniel Pips (ISIS bring his photo as example of this), stand at the forefront of those who make fun of the Prophet Muhammad. The following appeared in an ISIS journal: ${ }^{28}$

God "decreed that it would be a Prophet—returning as a follower of the sharī'ah of Muhammad...—who would deal the decisive blow to the dajjäl [the devil] and his followers, the cursed Jews, who have a history of betraying and even killing the Prophets of Allah. It would be one of the very Prophets whom they tried, but failed, to kill that would slay their "awaited king". 29

In May 2014, a France citizen of Algerian decent named Mehdi Nemouche, shot and killed four people at the Jewish Museum of Belgium before fleeing the scene. After he was arrested, it was revealed that this was one of ISIS' first operations against the Jews. In his luggage, the police found a video featuring the ISIS flag and ISIS claimed responsibility. ${ }^{30}$

\section{The Methods of the Jews in Leading a World Crusade Against Islam}

On February 23, 1998, Usāmah bin Lādin, al-Qā'ida’s leader, declared war against the Crusaders and the Jews. His starting point in this document was that America, together with the Jews, stood at the head of an anti-Islamic crusade. Christians and the Jews had joined together in order to topple the Islamic world in Iraq, Palestine and all of the other Islamic lands. According to bin Lādin, the goal of America's Middle Eastern policy was to ensure the survival of the Jewish State. To achieve this end, America believed that it was in its best interest to keep the Muslim world divided into mini-paper states. That is how, according to the document, the Jewish State is able to continue holding on to Jerusalem and slaughter Muslims there. ${ }^{31}$

\footnotetext{
${ }^{24}$ Albert J. Bergesen (ed.) The Sayyid Qutb Reader: Selected Writings on Politics, Religion and Society (New York and Abington: Routledge, 2008), 5-8, 54-56.

25 Raymond Ibrahim, The al-Qaeda Reader (New York: Random House, 2007), 128, 131.

26 "Dialogue with Sheikh Abū Mus'ab az-Zarqāwī", part 2, Al-Furqan, 2006.

27 Usāmah bin Lādin, "Practical Steps to Liberate Palestine", al-Sahab, Mar. 14, 2009.

28 "The Extinction of the Gray Zone", Dabiq: From Hypocrisy to Apostasy, Issue 7 (Feb. 2015), 59.

29 "Yahya: Lessons from a Shaid, Dabiq: Remaining and Expanding", Issue 5, (Nov. 2014), 4.

30 Jessica Stern and J.M. Berger, ISIS, The State of Terror (London: Wiliam Collins, 2016), 94, 201.

31 Raymond Ibrahim, The al-Qaeda Reader, 11-14; Mathias Küntzel, Jihad and Jew-Hatred, Islamism, Nazism and the Roots of 9/11 (New York: Telos Press, 2007), 132.
} 
In December 27, 2004, the al-Sahhab Institute published bin Lādin's letter "to the Muslims in Iraq and the Islamic nation in general". This letter was aired on al-Jazeerah:

The al-Q̄̄'ida organization welcomes the union with the warrior commander, honored comrade 'Abū Mus'ab az-Zarqāwī and his group. This is a tremendous step on the path to the unification of the efforts fighting for the establishment of a State of Truth and for uprooting of the Sate of the Lie. (Bukay, 2008, p. 280)

Zarqāwī used to say that "the road to Palestine is through Amman [Jordan]" ${ }^{32}$ The ISIS founder understood that the long-term target was Israel and the eradication of the Jewish state- even with mass destruction and missiles if necessary. ${ }^{33}$

Sulayman Abu Ghayth, explained after the September 11, 2001 attack, that:

America, in partnership with the Jews, is the head of corruption and decay, whether this is moral, conceptual, political or economic corruption, and it intends to propagate depravity and iniquity between people by means of the trash media and base methods of education. America is the reason for every injustice, wrong, and oppression to befall the Muslims. It is behind all of the disasters that have happened and continue to happen to the Muslims. It is drenched with the blood of the Muslims and [no one] can conceal or hide this. ${ }^{34}$

In this partnership, the Jews are dominant.

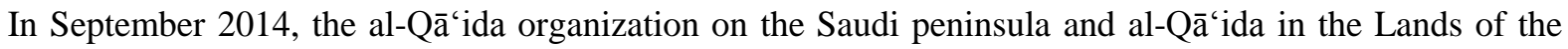
Islamic Maghreb, were encouraging the jihad fighters in Syria who belonged to the Islamic State, and Jabhat an-Nusrah li-Ahli ash-Shām (now Jabhat Fateh ash-Shām) to make peace with each other and instead focus on the common enemy. This active enemy, according to these al-Q'̄'ida organizations, the "Crusader campaign fighting Islam and the Muslims" is made up of Christian, Jews, Shiites and Alawite. ${ }^{35}$ ISIS publicity calls the Jews "the navigators" for all of the powers against Islam. The Jews, as part of their tricks, do not fight themselves but activate others to fight for them. Henry Kissinger, the former American Secretary of State and a former security adviser, is nicknamed "The Jewish Crusader" in the organization's journal. In an interview, Kissinger had explained that the danger from ISIS was less than the danger from Iran:

In the same interview, this arrogant and cowardly Jew said, "I think when we're dealing with a unit like ISIS, we should not get into a position where they can lead us by establishing ground forces. But we should set strategic objectives where we thwart any goal they set themselves, which we should be able to do by superior air power. And then, if we can enlist other countries or other more local groups to do the ground fighting, we might actually destroy them. ${ }^{36}$

The Jews and the Christians argue that their goal is to aid the weak and bring peace. According to the Caliph, Abu Bakr al-Baghdādī, their real goal is to convert the Muslims and steal Islamic resources. ${ }^{37}$ The Jews take advantage of the Arab rulers (the "near" enemy) and control them. The nuclear agreement with Iran is described as a change of policy where the Jews and the Crusaders decided to support the heretic Shiites and the atheist Kurds after they decided to neglect the tie with their previous Saudi puppet. ${ }^{38}$ Once again, the Jews stood at the head of the heretic camp and were navigating all that was happening in the area according to their needs and the way they were dealing with the Islamic State.

\footnotetext{
32 Joby Warrick, Black Flags, 65.

33 Ibid, 138-150.

${ }^{34}$ David Cook, Understanding Jihad, 207.

35 Robin Simcox, “AQAP's Ideological Battles”, 21.

36 "The Crusade Serving Iran and Russia", Dabiq: The Failed Crusade, Issue 4, Oct. 2014, 39.

37 “An Address from the Khalīfah on the Last Plot of the Apostates", Dabiq: They Plot and Allah Plots, Issue 9, May 2015, 53-54.

38 Ibid., 55-56.
} 
O Muslims, the tāghìt rulers who rule your lands ... are the allies of the Jews and Crusaders. Rather, they are their slaves, servants, and guard dogs, and nothing else. The armies that they prepare and arm and which the Jews and Crusaders train are only to crush you, weaken you, enslave you to the Jews and Crusaders, turn you away from your religion and the path of Allah, plunder the goods of your lands, and rob you of your wealth. This reality has become as obvious as the sun in the middle of the day. ${ }^{39}$

ISIS further argues that Jewish control over money enables them to support Muslims who are willing to cooperate with them and even convince them to betray Islam. In January 2015, the organization publicized its capture of a Mossad spy from within its ranks-A Palestinian resident of Jerusalem named Muhammad Sa'̄̄d Ismā'îl Musallam, who confessed that he was recruited by the Mossad in exchange for money and other creature comforts in order to betray the Islamic State. When interviewed, he spoke about his recruitment. He blamed his family and the rest of the Arabs who are cooperating with the Jews as murtaddin (Muslims who became heretics). ${ }^{40}$ His sentence was death by a shot to the head which was carried out by a young boy (Kais, 2015b).

Collaboration with Jewish factors is a widespread accusation by political rivals. Again, the motivation for this unacceptable relationship and the spiritual poison that is spread by the Jews is money or corruption. ISIS, when explaining the "Jewish influence" on Islamic religious leaders, point to 'ulamaa (religious scholars) from al-Azhar, the most important religious institutions in Egypt and the Arab world. For example, the Mufti Muhammad Syed at-Tantāwī (d. 2010), who served as the Mufti of Egypt and the Grand Imam of Al-Azhar, was presented as a collaborator with the Jews due to a photo of him shaking hands with the former Prime Minister of Israel, Shimon Peres. ${ }^{41}$ The Jews are also accused of spreading lies about Islam through their control of the world communication networks. This is the reason that the Islamic State organization sees the murder of the Jewish-American journalist, Steven Sotloff, as important enough to have had his head cut off in front of cameras in September 2014. Since he was a Jew, he was already deserving of the death penalty in the eyes of the organization without having to indicate his previous role in the advancement of the "crusade" against the Muslims:

The case of Steven Sotloff contains a direct refutation against those who portray western journalism and humanitarian aid as purely innocent, for this man was a Jew and citizen of the Jewish state (author's emphasis). In addition to his work for Crusader media including Time, National Interest, Foreign Policy, The Christian Science Monitor and the Long War Journal, he also "freelanced" for two Jewish publications-The Jerusalem Report and The Jerusalem Post. The war against Islam for the sake of tāghüt is a media war as well as a military and intelligence struggle. It is not surprising then to know that dozens of specialists were employed to hide his Jewish identity from the world prior to his execution. This intelligence operation was done in cooperation with the Jewish state and media. ${ }^{42}$

Steven Sotloff is a symbol of "America in partnership with the Jews". At his execution, the killer sent this message to Obama: "The life of this American citizen, Obama, depends on your next decision". ${ }^{43}$ It was promise of more bloodshed to come for Jews and Westerners alike.

\footnotetext{
39 Ibid., 55.

40 "Interview with a Spy Working for the Israel Mossad", Dabiq: From Hypocrisy to Apostasy, Issue 7, Jan. 2015, $26-30$.

${ }^{41}$ Dabiq: The Law of Allah or the Law of Men, Issue 10, Ramadan (Jun. 2015), 64.

42 “A Message from Sotloff to his Mother", Dabiq: The Failed Crusade, Issue 4, Oct. 2014, 47.

43 Jessica Stern and J.M. Berger, ISIS, The State of Terror, 4-5, 121.
} 


\section{What Is the Fate of the Jews?}

The fate of the Jews is simply death. The following was published in the second issue of Dabiq, during Ramadan 2014 and the war in Gaza:

As for the massacres taking place in Gaza against the Muslim men, women, and children, then the Islamic State will do everything within its means to continue striking down every apostate who stands as an obstacle on its path towards Palestine. It is not the manner of the Islamic State to throw empty, dry and hypocritical words of condemnation and condolences like the Arab tawäghìt [idolatry sinners] do in the UN and Arab League. Rather, its actions speak louder than its words and it is only a matter of time and patience before it reaches Palestine to fight the barbaric Jews and kill those of them hiding behind the gharqad [Jewish] trees - the trees of the Jews. ${ }^{44}$

Sheikh Omar Aub Sara, a resident of Kfar 'Aqeb in eastern Jerusalem and a preacher at al-Aqsa, explained ISIS' stand against the Jews (This sheikh was previously active in the Hizb al-Tahrir al-Islami [the Islamic Liberation party] but became a supporter of the Islamic State because Hizb al-Tahrir, despite its impassioned rhetoric in regard to jihad, lacks a military arm necessary for carrying out the Islamic vision of the Caliphate and supporting the spreading of its ideas) (Dalacoura, 2011, pp. 60-62). He sees ISIS as the military arm which carries out the slaughter of the Jews and their destruction. The jihad, according to his method, has turned into a fardh al-kifäya, a general requirement incumbent upon every Muslim in the world due to the declaration of Caliph Abu Bakr al-Baghdādī in regard to a jihad against heretics. ${ }^{45}$

I say to the Jews loud and clear: The time for your slaughter has come. The time to fight you has come. The time to kill you has come... Please do not leave in our hearts a single grain of mercy toward you, O Jews, because when the day of your slaughter arrives, we shall slaughter you without mercy. (Memri, 2014)

In the beginning of July 2014, right before Operation "Protective Edge" broke out, the Islamic State organization publicized the following warning on Twitter:

The Real Zionist Holocaust is Predicted in the Hadiths! The Hour [resurrection] will not take place until the Muslims fight the Jews and the Muslims kill them, and the tree will say: "Oh, Muslim, servant of God, there is a Jew behind me, kill him! The promised Holocaust..." (Rossomando, 2014)

On December 21, 2014, the Islamic State organization publicized an explicit call to kill Jews. ${ }^{46}$ It did not take very long after this call for Jewish blood to be spilled.

On January 8, 2015, Amedy Coulibaly likely shot and killed a police officer in Paris. The next day, he held up a kosher bakery and killed four Jewish hostages before the French police managed to kill him. Coulibaly had pledged allegiance to al-Baghdadi and was committed to ISIS' anti-Jewish ideology. The widow of Coulibaly, Hayat Boumeddiene, was sheltered by the Islamic State in Syria after the murders. ${ }^{47}$

\footnotetext{
44 "Foreword", Dabiq the Flood, Issue 2, Ramadan, Jul. 2014, 4. According to the apocalyptic prophecy in the Hadith collection of Sahīh Muslim and Sahīh al-Bukhārī, all the Jews will be killed by Muslims expect those that will hide behind gharqad trees.

${ }_{45}$ "Sheikh Indicted for Calling for "Slaughter of Jews", Times of Israel, Jan. 21, 2015. Available at http://www.timesofisrael.com/sheikh-indicted-for-calling-for-slaughter-of-jews/.

${ }_{46}$ Aryeh Savir, "ISIS Tweets Death to Jews", United with Israel, Jan. 4, 2015, available at http://unitedwithisrael.org/isis-tweets-death-to-jews/.

47 Michael Birnbaum, "Who is Kosher Market Suspect Amedy Coulibaly?" The Washington Post, Jan. 9, 2015; Michael Birnbaum and Souad Mekhennet, "Hayat Boumeddiene, Wife of Paris Attacker, becomes France's Most-Wanted Woman", The Washington Post, Feb. 2, 2015; Griff Witte and Brian Murphy, "Islamic State Magazine Claims Widow of Paris Attacker is in Syria", The Washington Post, Feb. 12, 2015.
} 
Al-Baghdādī explicitly admits Coulibaly's actions were the result of Al-Baghdādī's instructions. Coulibaly's name was listed together with additional ISIS activists who carried out acts of terror all around Europe, Canada, Australia, and the United States.

This is the order of the Khalīfah (hafidhahullāh). Either one performs hijrah to the wilāyāt of the Khilāfah or, if he is unable to do so, he must attack the Crusaders, their allies, the Rāfidah, the tawāghìt, and their apostate forces, wherever he might be with any means available to him. ${ }^{48}$

It is believed that the widening of the circle of support for the Islamic State in Libya, Northern Africa and the whole Arab world will lead, in the end, to the destruction of Israel and the Christian world. There are two places mentioned in the magazine where the ISIS flag will eventually fly-Jerusalem and Rome, the cradle of Judaism and Vatican City. That is the how the final subordination of the humanistic religions and others to Islam will be defined.

On the 20th of Muharram 1436 [November 13, 2014], the Islamic State officially announced its expansion into the Arabian Peninsula, Yemen, the Sinai Peninsula, Libya and Algeria and the establishment of a wiläyāt therein. The Khalīfah Ibrāhīm (hafidhahullāh) also accepted the bay'āt [loyalty oath] from all the groups and individuals who pledged allegiance from other lands. Thus, while the eyes of the world were all blinded and spellbound by the sorceries [sic] media "covering" the battle for "Ayn al-Islām, the eyes of the Islamic State were scanning East and West, preparing for the expansion that - by Allah's permission - would put an end to the Jewish State, Āl Salūl [derogatory name for the Saudi royal family $\left.\overline{\mathrm{A}} \mathrm{l} \mathrm{Sa} \mathrm{Cu}^{\mathrm{u}} \mathrm{d}\right]$, and the rest of the apostate tawāghit, the allies of the cross ... The flag of Khilāfah will rise over Bayt al-Maqdis [Jerusalem] and Rome, even if the Jews and Crusaders despise such. ${ }^{49}$

The war against the Jews and their supporters is worldwide. Even the last stabbing attacks were partly inspired by the Islamic State.

Amongst these brave knights of tawhīd and jihād was fifteen-year-old Farhad Khalil Mohammad Jabar, who on "2 October 2015" struck the Crusaders of Australia and killed one of their personnel. Thereafter, Faisal Mohammad carried the banner and his dagger to spear the Crusaders of America on "4 November 2015", spilling their filthy blood in their insecure homeland. Earlier, on "10 October 2015", sixteen year-old Ishāq Qāsim Badrān grabbed his blade and pierced citizens of the accursed Jewish state, filling the atmosphere with their screams. After Ishāq, Muhannad Khalīl al-"Aqabī carried his own weapon into a high security train station on "18 October 2015" and killed a soldier from an "elite unit" belonging to the Jewish army, causing the other cowardly soldiers to retreat. And on "9 November 2015", Anwar Abu Zeid - after repenting from his former occupation - attacked the American Crusaders and their apostate allies, killing two American Crusaders, two Jordanian apostates, and one South African Crusader. ${ }^{50}$

Ishāq Badrān was an Israeli resident of Kfar 'Aqeb who stabbed and injured two Jewish citizens who walked in Jerusalem's streets. He was shot and killed by the police. Muhannad Khalīl al-'Aqabī, another Israeli citizen, carried out a lone-wolf attack at Beer Sheva's Central Bus Station. Their attacks, according to an ISIS proclamation, were part of general attacks carried out against the West and the Jewish state.

\section{The Fighting in Iraq, Syria, Sinai Paves the Way for Palestine}

The Islamic State is a relatively new organization and one which does not hide its goals or its ambitiousness. In the eyes of the Syrian, Iraqi and all the other Muslim country organizations, ISIS has not yet

\footnotetext{
48 "An Address from the Khalifah on the Last Plot of the Apostates", Dabiq: They Plot and Allah Plots, issue 9, (May 2015), 54-55.

49 "Forward", Dabiq: Remaining and Expanding, Issue 5, Nov. 2014, 3.

50 "Foreword", Dabiq, Just Terror, Issue 12, Dec. 2015, 3.
} 
reached the stage of a bigger war against the Jews, the "far" enemy. This war will only come when the Islamic State will be strong and steady and will control the Arab countries around Palestine.

Abū 'Umar al-Baghdādī (rahimahullāh) said: "The Iraqi jihād brought back life to jihād̄̄ regions which had weakened a bit after their strength. It also prepared the path for attacking the Jewish State and retaking Bayt al-Maqdis [Jerusalem]., ${ }^{, 51}$

The war against the Kurdish minority in Iraq is also considered part of the war against the Jews and their allies. The organization emphasizes that many Kurdish fighters are in its service. Another goal of the fight is to remove Kurdish control over the oil fields that, according to ISIS, belong to the Muslims. ${ }^{52}$ Shaykh Abū Muhammad al-'Adnānī, the speaker of the Islami State organization, said: "We do not fight Kurds because they are Kurds. Rather we fight the disbelievers among them, the allies of the Crusaders and Jews in their war against the Muslims". 53

This opinion is not new. It was also the stand of al-Qa' ${ }^{-} i d a$ during the years of its war in Iraq as expressed by 'Ayman az-Zawāhirī, in an interview on September 2005. According to az-Zawāhirī, the Jewish intelligence services aided the Kurds in establishing a state in Iraq that would function under American protection. ${ }^{54}$

It is the opinion of ISIS that nothing will help the Jews and their allies. The Caliphate will expand until it will encircle Israel and, in the end, like in the period of Salāh ad-Dīn Yūsuf ibn Ayyūb (d. 1193), destroy Israel by a concentrated blow from all directions. The attempts to hurt the Islamic State will only cause it to be stronger and more determined in its fight against the heretics. ${ }^{55}$

Sinai is also a front against the Jews, an important step toward the liberation of Bayt al-Maqdis. This expansion brings the battle where the Jews hide behind their gharqad [Jewish] trees closer to the Muslims, by ridding the path of the obstacles manifested in the apostate regime and army of Fir'awn. Again, the mujāhidīn of Sinai faced opposition in the past from those jihād claimants who called for the continuation and the preservation of pacifist opposition even if such necessitated a termination of $j i h \bar{a} d$ and a collapse of tawhìd. They ignored the whispers of the unwise and fought the tāghüt while relying upon Allah until they were blessed by their Lord with victories and consolidation. ${ }^{56}$

The Wilayat Sinai of the Islamic State is a powerful branch of the organization. On October 31, 2015, a passenger plane traveling from Sharm el-Sheikh, Egypt to Saint Petersburg, Russia, crashed in northern Sinai killing all 224 people aboard. ISIS's Wilayat Sinai branch claimed responsibility for this attack. ${ }^{57}$ Although at present, Wilayat Sinai has focused its struggle on the Egyptian Army, it is already preparing for the next battle with Israel. In March 2016 there was a report that: “The ISIS affiliate in Egypt's Sinai peninsula plans to carry out a 'big operation' in southern Israel which will include an attack on the resort city of Eilat, a militant close to the group warned" ${ }^{58}$ This will only be the beginning according Abu al-Ayna al-Ansari, a Salafist movement senior official in the Gaza Strip. In his interview he said: "The Islamic State educates its people that Israel and the United States are the leaders of the infidels and we believe that Israel should be disappeared". 59

\footnotetext{
51 "The Islamic State Founders on Signs of the Hour", Dabiq: The Failed Crusade, Issue 4, Oct. 2014, 35-36.

${ }^{52}$ Abd al-Bari 'Atwan, Al-Dawla al-Islamiya, al-Jadur, al-Tuhsh, al-Mustakbal (Beirut: Dar al-Saqi, 2015), 39.

53 The official spokesperson for ISIS: "Indeed your Lord is Ever Watchful", Dabiq: The Failed Crusade, Issue 4, Oct. $2014,9$.

"Unifying the Ranks", Dabiq: Remaining and Expanding, Issue 5, Nov. 2014, 12.

${ }^{54}$ Full translation by Raymond Ibrahim, The al-Qaeda Reader, 179.

55 "Unifying the Ranks", Dabiq: Remaining and Expanding, Issue 5, Nov. 2014, 12-13, 33.

56 "Sinai", Dabiq: Remaining and Expanding, Issue 5, Nov. 2014, 29.

57 Jessica Stern and J. M. Berger, ISIS, The State of Terror, 285.

58 "ISIS Branch in Egypt's Sinai Planning Big Operation in Southern Israel”, The Jerusalem Post, Mar. 27, 2016.

59 Ibid.
} 
According to ISIS, the Jews are afraid of ISIS' rising strength. Netanyahu is described as someone who is pleading persistently and non-stop for the West to fight ISIS with more strength. Netanyahu recognizes the danger of ISIS to the Jews as can be seen in the following interview:

Benjamin Netanyahu - the head of the Jewish state - was asked on the CBS News program "Face the Nation" if the Islamic State posed a threat to the Jewish state. He replied: "Absolutely. I mean ISIS has got to be defeated because it is doing what all these militant Islamists are trying to do. They all want to first dominate their part of the Middle East and then go on from there for their twisted idea of world domination. [...] Essentially, they want to accumulate enough power to carry out their mad ambitions. So, that is the danger with ISIS. It is creating a statement. It makes two million petrodollars a day. Its weapons have been taken from the Iraqi army and so on. And it is dangerous, no question". 60

\section{Conclusions}

It is surprising that in the 21 st century, only 70 years after the Holocaust, Jews are once again presented as pure evil. The Jews, as 'Ayman az-Zawāhirī, explains are "the leaders of those who spread corruption and tyranny on the face of the earth". ${ }^{61}$ They worship the devil and his servants. They curse the Prophet Muhammad. The Islamic view in regard to the Jews as reflected by ISIS exists in terms and expressions taken from the seventh century and from Muhammad and his struggle against the Jews.

Every Jew is presented as an enemy of the Islamic nation. Steven Sotloff was decapitated first of all because he was a Jew and only afterwards due to his crimes in the service of the media and his distribution of lies about Islam. Sotloff is also a symbol for "America in partnership with the Jews". Binyamin Netanyahu, who is described as the tăgh $\bar{u} t$ of the Jews, is a leader who does not rule according to Islamic law. Neither do many other leaders in the Arab world according to ISIS. Egypt, Jordan and the other Arab state are helping Israel to survive. After the jihad against the "near" enemy of the Arab states will succeed, the turn of the Jewish State will arrive.

Jew hatred, beginning with Hassan al-Banah, Haj' Amin al-Husayni, Siyyad Qutb and those who continued in their path - from al-Qā'ida - Sheikh Abdullah Azzam, Osama Bin Laden and 'Ayman az-Zawāhirī - and from ISIS - Abū Bakr al-Baghdādī - are no different in their hatred of the Jews than those that came before them. There are, however, three unique characteristics to the Jew-hatred of the Islamic State organization.

(1) According to the doctrine of the Islamic State, the war against the Jews is a global war and not just a localized war in Israel or on its borders as believed by Hamas or the Palestinian Islamic Jihad. The Jews are the embodiment of total evil and Israel is just the symptom of this evil. The Jews are the servants of the devil and that is why they have a sentence of death anywhere in the world where they are or where they will be caught. The conflict with the Jews is not a nationalistic conflice but a religious one. World Judaism, which rules over America and Russia, are fighting against Islam and the Caliphate. In light of this, the attack at the HyperCacher in Paris is not surprising. One is allowed to hurt Jews wherever they are and at any time. This has already been quoted above from Qutb and other Muslim fundamentalist theologians who see the relationship with the Jews as a cultural war between Islam and the Judeo-Christian culture. In ISIS' view, this is a life and death fight.

(2) In the eyes of the Islamic State, the destruction of Israel as the "far" enemy is a long-term goal. Israel will only be destroyed after the Islamic State has become established in the areas captured in Syria and Iraq and

\footnotetext{
60 “The Enemy's Words", Dabiq: Al Qā'idah of Waziristan-A Testimony from Within, Issue 6, Dec. 2014, 56-57.

61 Raymond Ibrahim, The al-Qaeda Reader, 66.
} 
perhaps in additional places. The Islamic State even aims to capture significant areas in the Sinai through the Ansār Bayt al-Maqdis organization and the defeat of the modern Pharaoh's army (Egypt's president as-Sisi). The uniqueness of ISIS is in its ability to turn its words in regard to the extermination of Israel into acts. The ability of the Islamic State organization to control parts of the Israeli northern border with Syria and to show an impressive presence on the Israeli southern border in Sinai creates, for the first time since the Yom Kippur War (1973), the threat of an integrated attack on Israel on two fronts by one command.

(3) Jihad has been turned into a general requirement (fardh al-kifāya) which is incumbent on every Muslim in the world from the power of the decree of Caliph Abū Bakr al-Baghdādī. Sheikh Omar Abu-Sara, former Hizb al-Tahrir activist, understood this and as do other additional Hizb al-Tahrir activists from the West Bank who support him. ${ }^{62}$ Likewise, Amedy Coulibaly understood this when he carried out the massacre at the HyperCacher in Paris. Abū Bakr as Caliph is still a matter of disagreement among Muslims but there is no doubt that there exists a strong pull in that direction. In order to carry out ISIS ideology, many Muslim youth from all around the world volunteer for the Islamic Caliphate, the one that Hizb al-Tahrir has pushed for, ever since its establishment in 1953.

Hatred for the Jews which is reflected in the Dabiq journals and all the other ISIS publications, is only an additional stage in the chain of anti-Jewish propaganda. Hatred for the Jews as those who represent evil and who serve the devil aids ISIS in presenting its war as a justified war against an army of infidels led by the Jews and followed by the Crusaders, (Christians) Shiites, the Alawite, the Kurds and the Druze against the army of the believers which includes all of the Muslims in the world. According to Abu Mus'ab az-Zarqāwī: "The spark has been lit here in Iraq and its heat will continue to intensify - by Allah's permission - until it burns the Crusader armies in Dābiq".

\section{References}

Brooke, S. (2011). The Near and Far Enemy Debate. In I A. Moghadam \& B. Fishman (Eds.), Fault Lines in Global Jihad, Organizational, Strategic and Ideological Issures (pp. 47-62). Abingdon: Routledge.

Bukay, D. (2008). From Muhammad to Bin Laden, Religious and Ideological Sources of the Homicide Bombers Phenomenon. New Brunswick and London: Transaction Publishers.

Dalacoura, K. (2011). Islamist Terrorism and Democracy in the Middle East. New York: Cambridge University Press.

Efraim, I. (2015). Analysis: How dangerous is ISIS to Israel?. Retrieved from http://www.jpost.com/Middle-East/ISIS-Threat/Analysis-How-Dangerous-is-ISIS-to-Israel-415499

Eric, W. (2015). Islamic Resistance to Imperialism. Atlanta, GA: Clarity Press.

Joby, W. (2015). Black Flags, The Rise of ISIS. New York: Anchor Books.

Kais, R. (2015a). ISIS in Hebrew: We will make you pay for every crime. Retrieved from http://www.ynetnews.com/articles/0,7340,L-4715343,00.html

Kais, R. (2015b). ISIS Video Purportedly Shows Child Executing “Israeli Spy". Retrieved from http://www.ynetnews.com/articles/0,7340,L-4635622,00.html

Memri, T. V. (2014). Preacher at Al-Aqsa Mosque Omar Abu Sara to the Jews: We Shall Slaughter You Without Mercy. Retrieved from http://www.memritv.org/clip/en/4657.htm

Patterson, D. (2015). Anti-Semitisim and its Metaphysical Origins. New York: Cambridge University Press.

Rossomando, J. (2014). ISIS Threatens to Commit Another Holocaust against Jews. Retrieved from http://www.algemeiner.com/2014/07/08/isis-threatens-to-commit-another-holocaust-against-jews/

Yassin, M. (2005). What al-Qāida Really Wants. Retrieved from http://www.spiegel.de/international/the-future-of-terrorism-what-al-qaida-really-wants-a-369448.html

${ }^{62}$ Stated by members of the West Bank security forces who asked not to publicize their names. 